\title{
Tourism entrepreneurship policy: a hybrid MCDM model combining DEMATEL and ANP (DANP)
}

\author{
Saeed Jafari-Moghadama ${ }^{\mathrm{a}}$, Mohammad Reza Zali ${ }^{\mathrm{b}}$ and Hadi Sanaeepour ${ }^{\mathrm{c}^{*}}$
}

\author{
C H R O N I C L E \\ Article history: \\ Received September 3, 2016 \\ Received in revised format: \\ October 22, 2016 \\ Accepted December 27, 2016 \\ Available online \\ December 312016 \\ Keywords: \\ Tourism policy \\ Entrepreneurship \\ New hybrid MCDM model \\ DEMATEL-based ANP (DANP)
}

a. Department of Entrepreneurship Development, Faculty of Entrepreneurship, University of Tehran, Tehran, Iran ${ }^{b}$ Department of Corporate Entrepreneurship, Faculty of Entrepreneurship, University of Tehran, Tehran, Iran cPh.D. Candidate, Department of Entrepreneurship Development, Faculty of Entrepreneurship, University of Tehran, Tehran, Iran

\section{A B S T R A C T}

\begin{abstract}
Small and Medium Enterprises (SME's), and Entrepreneurial businesses (EB) play an important role in tourism since tourism has increasingly become the largest economic sector. Entrepreneurships known as a mean of economic development and policymakers are looking for creating a competitive and dynamic entrepreneurial economy. The aim of this study is to present a model for entrepreneurship tourism policy by using entrepreneurship development framework, which interacts with economic development. To this purpose, entrepreneurship policy dimensions are weighted and prioritized by tourism entrepreneurs, tourism policymakers and experts using decision-making trial and evaluation laboratory (DEMATEL) technique and Analytical Network Process (ANP) technique. First, DEMATEL technique is used to identify complex relationships, and to form a network relationship map. Then, ANP technique is used to calculate the influential weights of policy criteria. Results show that policymakers for entrepreneurship development in tourism need to consider basic requirements factors. In addition, they should improve efficiency enhancer criteria as well as innovation driver criteria. Also, the relationship among dimensions and their influences on each other are illustrated. Using the capabilities of this method, we can determine the casual relationships between dimensions and criteria and identify priorities for policy.
\end{abstract}

(C) 2017 Growing Science Ltd. All rights reserved.

\section{Introduction}

Nowadays, in many countries, tourism is considered as the primary source of revenue, employment, growth of private sector and development of infrastructure. World Tourism Organization reports show that tourism would be increasingly developed to become the largest economic sector, as the world's number one industry to 2020 (UNWTO, 2011, p. 26). Then, one of every 11 jobs and $30 \%$ of services exports are devoted to tourism (UNWTO, 2015; Hamzah, 2004).

\footnotetext{
* Corresponding author.

E-mail address: hadisanaeepour@ut.ac.ir (H. Sanaeepour)

(C) 2017 Growing Science Ltd. All rights reserved.

doi: $10.5267 /$ j.dsl.2016.12.006
} 
Iran's statistics indicate tourism industry has been growing and a portion of tourism in gross domestic product and employment is increasing, but it is ineffectiveness and noncompetitive (Blanke \& Chiesa, 2013) because of the high capacity of tourism absorption in Iran. Although, the competitive advantage of tourism and the role of tourism in generating income, employment and national economic growth has been emphasized in the recent Iran's Development Plan (Iran's 6th Development Plan, 2016-2021). Evidence and policy documents indicate the lack of a comprehensive policy in tourism. Comprehensive policy contains continuous process of formulation, implementation and evaluation. However, in many policy statements attention on policy formulation phase and other phases has been ignored.

The result of inattention to tourism policy suggests that presently there is neither a national policy (based on the regulated framework) in the country's tourism sector, nor any evidence of an attempt to design a model of entrepreneurship development policy in the sphere of tourism by either public authorities or private sector. This is despite the fact that in countries where tourism plays a major role in the development, development policies have been formulated and the roles and duties of public and private sector has been specified. For the purposes of income and employment generation, tourism policymaker setup policies aimed at supporting entrepreneurial activities in tourism and encouraging people to develop entrepreneurship in tourism (Saufi, 2013, p. 11-12). In recent years, there has been some interests on the development of tourism businesses by policy makers but few studies have been accomplished in this regard (Thomas et al., 2011, p. 963).

Saufi (2013) noted that entrepreneurship in tourism has received little attention; however there are numerous studies on entrepreneurship and tourism, as two separate issues (Saufi, 2013, p. 11-12). Tourism is formed of multiple businesses which provide a variety of services for tourists. Tourism business involves in various fields such as transportation, hospitality, travel and tour agents, advertising and promotion, finance and insurance, recreation, etc. (Uriely, et al., 2002, p. 88). Also, tourism has provided the ability of market opportunity identification and products development and created new opportunities for the use of resources (Lordkipanidze et al., 2005; Decelle, 2004).

Entrepreneurship is seen as a mean of economic growth and social development (Tsai \& Kuo, 2011) and policy-makers are looking to find the answer to the question of how to create a competitive and dynamic entrepreneurial economy (Stevenson \& Lundström, 2001). Because businesses play an important role in tourism, in this study we present a model for entrepreneurship tourism policy. We also choose a famous model of entrepreneurship development as a basis and entrepreneurship policy dimensions. This study, by using the economic development Michael Porter's theory, endeavors to fill the existing gap (Ács, et al., 2016, p. 17).

For this aim, a new hybrid Multi Criteria Decision Making (MCDM) model is anticipated assessed by expert groups. A decision-making trial and evaluation laboratory (DEMATEL) is used to identify complex relationships and to form a network relation map (NRM). Then, the DANP (DEMATELbased ANP) method is used to calculate the influential weights of criteria to solve problems of dependence and feedback among criteria and alternatives (Liu et al., 2012). Then, effects of causal relationships between dimensions and criteria for entrepreneurship policy in tourism are evaluated, and relationship between dimensions and criteria are illustrated by DEMETEL technique. Finally, dimensions and criteria are prioritized and they are weighted by ANP technique. Afterwards, we present an empirical case for tourism policy in Iran, and expectantly contribute to tourism policy system.

\section{Review of entrepreneurship policy in tourism}

Policy is a multifaceted phenomenon. In summary, Policy is a set of relatively stable and purposeful action provided by a person or group of actors for a public problem or general concern (Anderson, 2004). From the perspective of Hall and Jenkins (2004), tourism policy includes all government choices to do or not to do in tourism. Tourism policy also includes researchers' insight about the extensive research realm (Garcia, 2014, P. 34). Entrepreneurship policy is a aguidance of economic and social 
activities for people and their businesses (Rigby \& Ramlogan, 2013) and means for promoting entrepreneurship, which can be focused on pre-and post-launch businesses (Lundström \& Stevenson, 2002). Entrepreneurship policy is a new approach to policy making that focuses on individuals and SME's that focuses on corporate and companies (Norback et al., 2014, p. 2). Entrepreneurship policy involves correcting macroeconomic policy, exchange rates, trade and industrial policies and governance improvement (Ács \& Virgill, 2010, P. 485). Entrepreneurship policy is a tool to promote entrepreneurship. It aims to make an impact on the process of business creation and designed based on the three areas of motivation, opportunity and skill. Also its primary purpose is to encourage and motivate more people towards entrepreneurship (Stevenson \& Lundström, 2001, p. 4).

Research carried out in the study of entrepreneurship policy shows several factors are effective such as the development of training programs and consulting, infrastructure and financial support, R \& D (Redford, 2012; Audretsch et al., 2007; Ács \& Szerb, 2007; Henrekson \& Stenkula, 2010), culture of entrepreneurship, intellectual property rights (Audretsch et al., 2007; Ács \& Szerb, 2007; Henrekson \& Stenkula, 2010), empowering entrepreneurs and knowledge commercialization, create entrepreneurial economy, increase the level of entrepreneurial activities and access to foreign technology, and tax support (Ács \& Szerb, 2007), improving the environment, providing economic incentives, political, cultural and structure, access to resources (Stevenson \& Lundström, 2007) and formal institutional factors, namely financial, government policies, research and development, business infrastructure and services and informal institutional factors such as social and cultural norms, setting up business opportunities, develop skills, social image entrepreneurs, and entrepreneurship development in community (Alvarez et al., 2011; Audretsch et al., 2007).

Research made on tourism policy suggests that factors such as infrastructure development, create the perfect image of the country at the international level, the balance of political and financial support (Garcia, 2014), enhancing skills and knowledge, promotion of technical equipment, legal support, financial support and acceptance of the community (Najda-Janoszka \& Koperaa, 2014), provide incentives, development of inter-agency cooperation, facilitate cooperation and coordination (Wang \& Ap, 2013), strengthening of entrepreneurial characteristics such as risk-taking, innovation and opportunity recognition, education and training, technology development and financial support (Jaafar et al., 2011; Nybakk \& Hansen, 2008).

Few studies have presented a method for assessing wrapped national tourism policies (Liu et al., 2012, p. 413). For example, Hall and Jenkins (2004) noticed how some aspects of entrepreneurship policy can affect tourism. They proposed framework to show how different types of policies can be effective on the business development. Although this could partly compensate for the lack of research in this area, for future research, the wide range of effective policies on Entrepreneurship in Tourism is required (Thomas et al., 2011, p. 968). Garcia (2014) studied tourism policy in Spain and Portugal with the comparative method. The results show that external factors (bad country image, isolation and falling away toward tourism) and internal factors (political instability, lack of capital and poor infrastructure) influenced on current growth rates of tourism. He knows that entrepreneurship policy in tourism is a complex and interdisciplinary that needs supplementary investigation (Garcia, 2014). Jaafar et al. (2011) studied entrepreneurship in the tourism industry and offered recommendations for developing country. They determined that demographic characteristics of tourism SME's was directly related to their survival. Managers should also strengthen knowledge and skills, and the government can play an effective role in tourism promotion (Jaafar et al., 2011). Most researchs on entrepreneurship policy, insist on several factors that are not designed specifically for tourism and tourism businesses. Although some of these studies acquire some theoretical values, but few studies have focused on policies of tourism businesses (Thomas et al., 2011, p. 968). With regards to these studies, in previous studies people only attended to some factors influencing on tourism policy. 


\section{Conceptual frameworks}

In this study, we use global entrepreneurship development Index (GEDI) introduced by Acs and Szerb (2010). In this model, correlation between economic development and global entrepreneurship development Index (GEDI) between countries is investigated. Different levels of development are dependent on different stages of economic development (Ács \& Szerb, 2010). In this theory, development is classified into factor-driven, efficiency-driven and innovation-driven countries. This classification follows the 2008 Global Competitiveness Report which was introduced by Porter and is related to entrepreneurship interact with economic development (Bosma et al., 2009, p. 4).

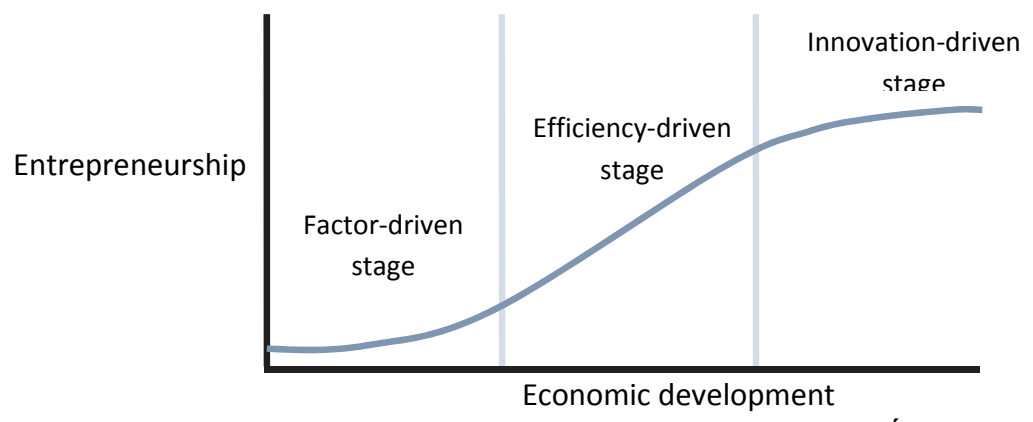

Fig. 1. The S-Curve of Entrepreneurship (Ács, et al., 2016, p. 19)

The factor-driven economy requires establishment of some basic requirements such as infrastructure, institutions for economic development. It features traditional agriculture, raw materials extraction and hard centralization. The efficiency-driven economy requires improving the efficiency enhancer factors such as market efficiency and human resources, technological readiness, etc. Society becomes industrialization and benefits caused by large scale productions. Large companies dominate the economy, but there is a corner for SME's. The innovation-driven economy is also innovation driving factors such as research and development, property rights, etc. In this stage, Knowledge-based economy and services, developed and innovative entrepreneurial activities are higher (Ács, et al., 2016, p. 17).

\section{Building a new hybrid MCDM model for entrepreneurship policymaking}

In this study, we use DANP model for evaluation and relationship entrepreneurship policymaking dimensions and criteria in tourism. Tzeng and Huang (2011) indicate that methodology of MCDM enables us to consider multiple criteria at the same time and also help the policy makers assess the best options by sorting cases according to the characteristics or criteria (Liu et al., 2012, p. 415). DANP is a type of MCDM model and a hybrid model, which combines DEMATEL and ANP to verify the effect of all dimensions and criteria, and to determine the importance of each factor (Chen et al., 2011, p. 910). So in the first step of this process, influential network relationship is established by a hybrid MCDM model with the DEMATEL technique and in the second step, the quantity of influential weights can be obtained with the DANP. Also the influential weights of the DANP resulting from the network relation map (NRM), is based on the total influence matrix $T$ of the DEMATEL technique (Hu et al., 2014, p. 4404).

This study seeks to determine the influence relationship among dimensions and related criteria with the DEMATEL method and measures the weights of each factor by ANP. DANP is a novel combination of DEMATEL and ANP, adopted to calculate the weight of policy criteria. DANP proposed by Ou Yang et al. (2008) to overcoming problems by recognizing the dependence and feedback of elements and factors. They proved that DANP compared with ANP is more useful in the real world (Liu et al., 2012, p. 415). 


\subsection{Identifying dimensions and criteria for entrepreneurship policymaking in tourism}

In this section, we identify dimensions and criteria for entrepreneurship policymaking in tourism. As mentioned earlier, is this study, we use GEM model. Therefore in this theory, we have three dimensions classified into factor-driven countries, efficiency-driven countries and innovation-driven. Also related criteria for these dimensions are classified in Table 1.

\section{Table 1}

The dimensions of influence and criteria

\begin{tabular}{ll}
\hline Dimension & Criteria \\
\hline \multirow{3}{*}{ Basic Requirements $\left(\mathbf{D}_{\mathbf{1}}\right)$} & Legal and administrative framework $\left(\mathrm{C}_{1}\right)$ \\
& Development of infrastructure $\left(\mathrm{C}_{2}\right)$ \\
& The stability of the business environment $\left(\mathrm{C}_{3}\right)$ \\
& Essential health care and basic education $\left(\mathrm{C}_{4}\right)$ \\
\hline \multirow{5}{*}{ Efficiency Enhancers $\left(\mathbf{D}_{2}\right)$} & Product and service market efficiency $\left(\mathrm{C}_{5}\right)$ \\
& Labor market efficiency $\left(\mathrm{C}_{6}\right)$ \\
& Sufficient technological readiness $\left(\mathrm{C}_{7}\right)$ \\
& Higher education $\left(\mathrm{C}_{8}\right)$ \\
& The efficiency of financial markets $\left(\mathrm{C}_{9}\right)$ \\
& The effective size of the market $\left(\mathrm{C}_{10}\right)$ \\
\hline & Entrepreneurial Finance $\left(\mathrm{C}_{11}\right)$ \\
& Government Policy $\left(\mathrm{C}_{12}\right)$ \\
\hline Intellectual property rights $\left(\mathrm{C}_{13}\right)$ \\
& R\&D transfer $\left(\mathrm{C}_{14}\right)$ \\
\hline \multirow{3}{*}{ Innovation Drivers $\left(\mathbf{D}_{3}\right)$} & Physical infrastructure $\left(\mathrm{C}_{15}\right)$ \\
& Cultural and social norms $\left(\mathrm{C}_{16}\right)$ \\
& Government Entrepreneurship Programs $\left(\mathrm{C}_{17}\right)$ \\
& Entrepreneurship education $\left(\mathrm{C}_{18}\right)$ \\
& Entry regulation $\left(\mathrm{C}_{19}\right)$ \\
\hline & Commercial and Legal infrastructure $\left(\mathrm{C}_{20}\right)$ \\
\hline
\end{tabular}

\subsection{Clarifying interrelations between dimensions and criteria}

In this section, for clarifying interrelations between dimensions and criteria for entrepreneurship policymaking in tourism, we use The S-Curve of Entrepreneurship (Acs, et al., 2016, p.19) and construct our conceptual framework based on this theory.

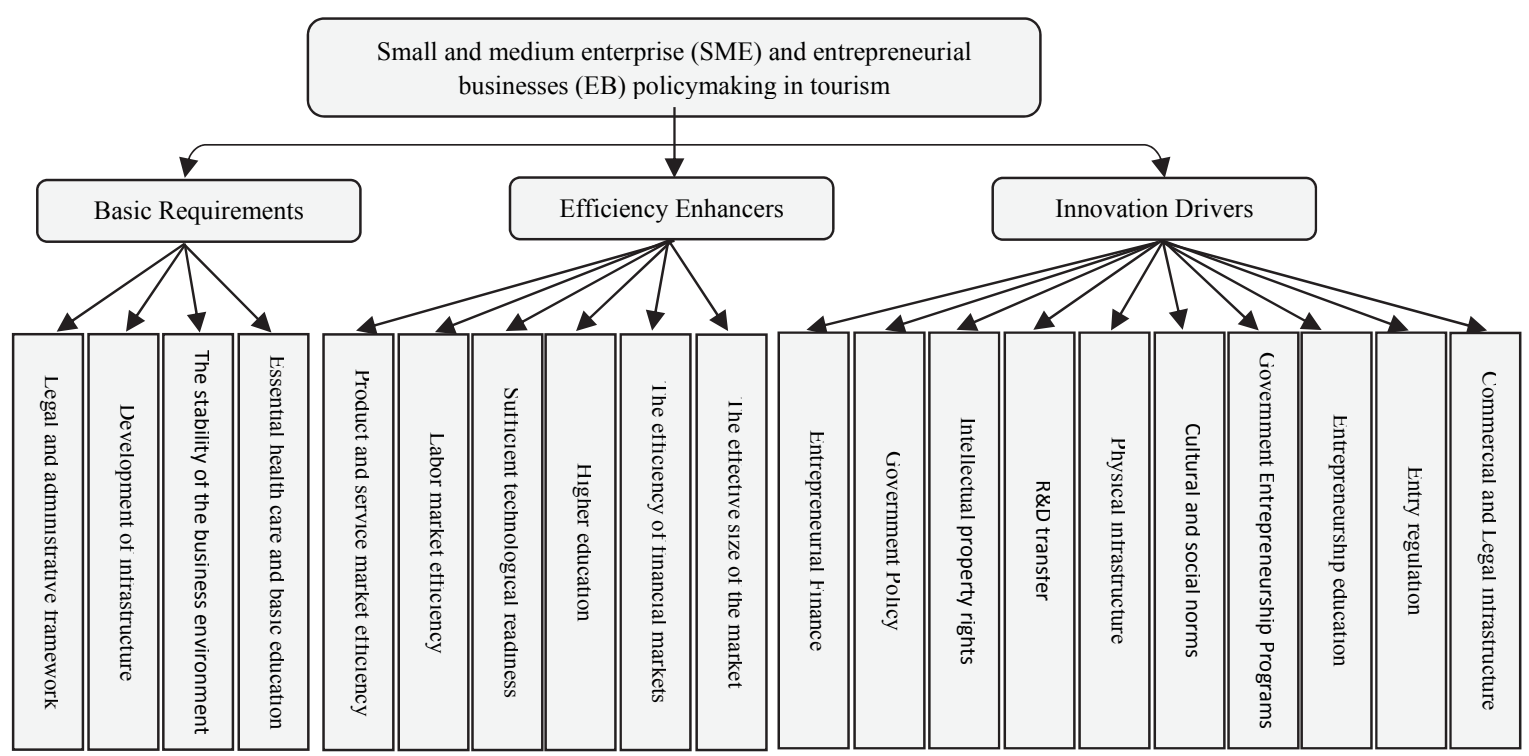

Fig. 2. Conceptualized framework of tourism entrepreneurship policymaking

In this theory, economic development is investigated in three levels of Factor-driven, Efficiency-driven and Innovation-driven. Therefore, for economic development in each level, former level must be given. 
In Fig. 2, we illuminate conceptual framework for tourism entrepreneurship policymaking and show interrelations between dimensions and criteria.

\subsection{DANP technique for building an a network relation map (NRM)}

The DEMATEL-based ANP technique (DANP) was used to investigate and to solve complicated problems that decision makers is concerned. In this method, matrix and related math theories are used to calculate the cause and effect on each element. This method can convert the relationship between criteria into logical structural model of the system. DANP has been widely used for complex problems (see Fig. 3). However, this method has not often been used in the context of tourism and hospitality (Liu et al., 2012, p. 416-417). The DANP method summarized as follows.

Step 1: Construct the measure scales of the direct relation matrix. This step is related to assessment experts in tourism, entrepreneurship and policymaking. A survey was conducted via questionnaires distributed to these experts comprised of 19 expert policymakers. The assessment is accomplished by interaction between criteria by pair-wise comparisons and score direct influence. The scale used changes from 0 to 4 , with scores represented by natural language: no influence (0), low influence (1), middle influence (2), high influence (3), and excessive influence (4).

Step 2: Calculate the direct-influence matrix by scores. After comparison, the direct-influence matrix can be obtained from the convergence of expert opinion where $\mathrm{n} \times \mathrm{n}$ matrix $G$, is denoted as the degree to which the criterion $i$ affects the criterion $j$. Matrix $G$ is acquired by using Eq. (1). Thus, the matrix $G=\left[g_{c}^{i j}\right]_{n \times n}$ of direct relationships can be obtained.

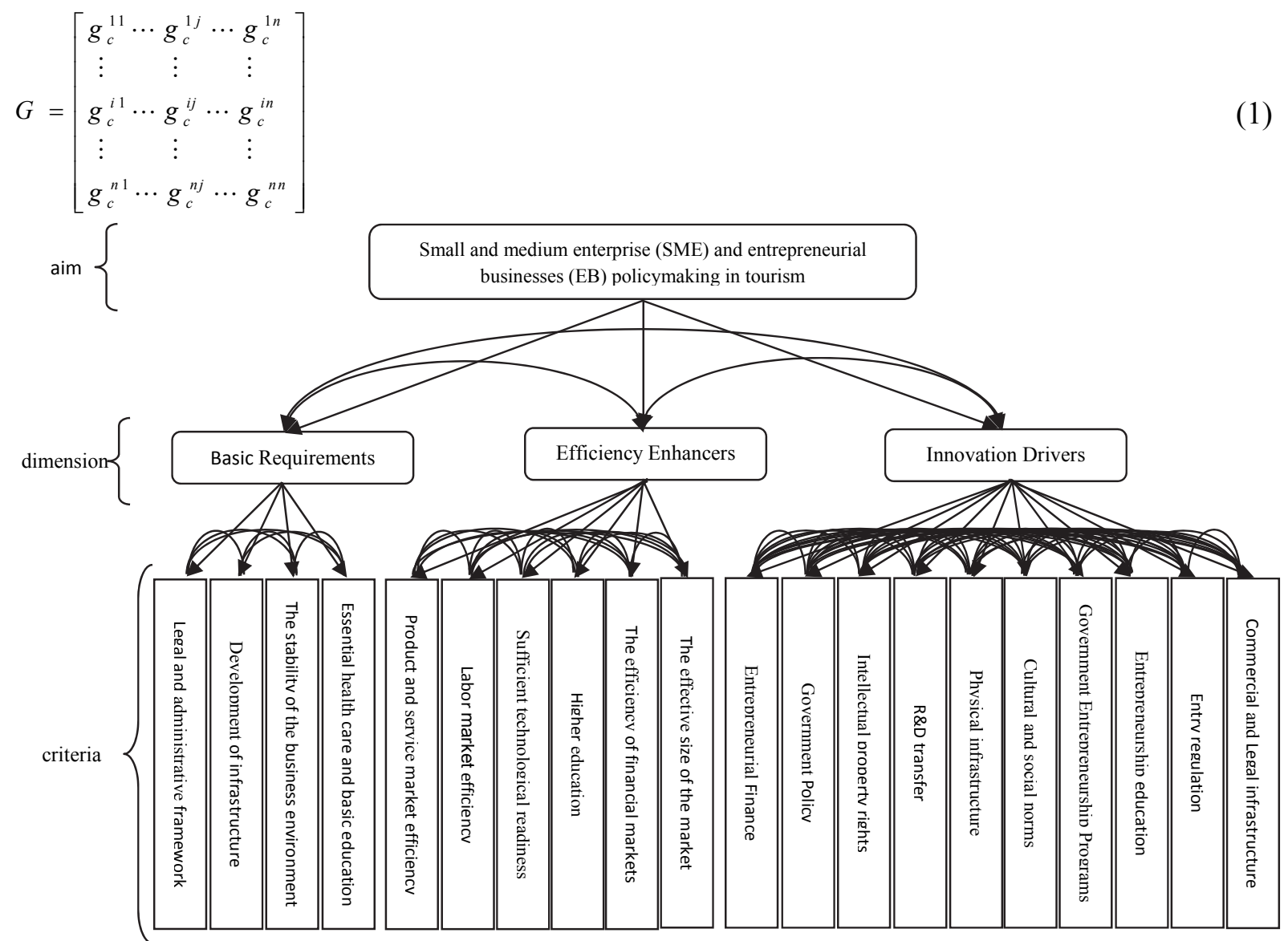

Fig. 3. Analytic framework of tourism entrepreneurship policymaking 
Step 3: Normalize the direct-influence matrix G. The normalized matrix $X$ is acquired by using Eq. (2). Its diagonal elements are zero, and the maximum sum of rows or columns is one.

$$
\begin{aligned}
& X=v G \\
& \text { where } \\
& v=\min _{i j}\left\{\frac{1}{\max _{i} \sum_{j=1}^{n} g_{c}^{i j}}, \frac{1}{\max _{i} \sum_{i=1}^{n} g_{c}^{i j}}\right\}, \quad i, j \in\{1,2, \ldots, n\}
\end{aligned}
$$

Step 4: Attain a total-influential matrix T. When the normalized direct-influence matrix $X$ is obtained, the total-influential matrix $T$ of the NRM can be obtained from Eq. (3), (Chiu et al., 2013).

$$
\begin{gathered}
T=\operatorname{lim~k} \rightarrow \infty\left(\mathrm{X}^{1}+\mathrm{X}^{2}+\ldots+\mathrm{X}^{k}\right) \\
T=\left[\begin{array}{rrrr}
t_{11} & t_{12} & \ldots & t_{1 n} \\
t_{21} & t_{22} & \ldots & t_{2 n} \\
\vdots & \vdots & \ddots & \vdots \\
t_{n 1} & t_{n} & \ldots & t_{n n}
\end{array}\right]
\end{gathered}
$$

Step 5: Analyze the results by acquire $r_{i}+s_{i}$ and $r_{i}-s_{i}$. At this stage, the row sums and the column sums of the matrix components are separately expressed as vector $r$ and $s$ in which $r_{i}$ and $s_{i}$ are the sum of row and the sum of columns of $T$ respectively. To finalize the procedure, all calculated $\left(r_{i}+s_{i}\right)$ and $r_{i}-s_{i}$ are performed by using Eq. (4) and (5). The horizontal axis vector $\left(r_{i}+s_{i}\right)$ is defined by adding $r_{i}$ to $s_{i}$ to illustrate the importance of the criterion. Similarly, the vertical axis vector $\left(r_{i}-s_{i}\right)$ is defined by subtracting $r_{i}$ from $s_{i}$ which may divide the criteria into a causal and affected cluster. In general, when $\left(r_{i}-s_{i}\right)$ is positive, the criterion is part of the causal group; i.e., criterion $i$ affects other criteria. By contrast, if $\left(r_{i}-s_{i}\right)$ is negative, the criterion is part of the affected group; i.e., criterion $i$ is influenced by other criteria. Therefore, a causal graph can be achieved by mapping the data set of $\left(r_{i}+s_{i}, r_{i}-s_{i}\right)$ to provide a valuable approach to decide how the preferred values in each dimension and criterion can be improved.

$$
\begin{aligned}
& r=\left[\sum_{j=1}^{n} t_{c}^{i j}\right]_{n \times 1}=\left[t_{c}^{i}\right]_{n \times 1}=\left(r_{1}, \ldots, r_{i} \ldots, r_{n}\right)^{\prime} \\
& s=\left[\sum_{i=1}^{n} t_{c}^{i j}\right]_{1 \times n}^{\prime}=\left[t_{c}^{j}\right]_{n \times 1}=\left(s_{1}, \ldots, s_{j} \ldots, s_{n}\right)^{\prime}
\end{aligned}
$$

Step 6: Attain Total-influential criteria matrix $T_{C}$ and Total-influential dimensions matrix $T_{D}$. The $T_{C}=\left[t_{C}^{i j}\right]_{n \times n}$ pertains to $n$ criteria, while the $T_{D}=\left[t_{D}^{i j}\right]_{m \times m}$ is devoted to $m$ dimensions from total influential matrix $T$.

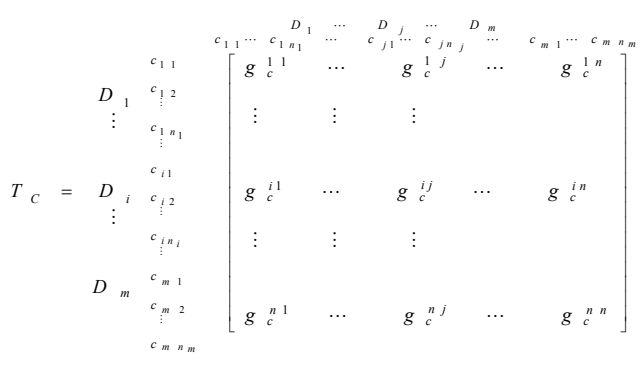


Step 7: Find the normalized Total-influential dimensions matrix $\boldsymbol{T}_{D}{ }^{\text {nor }}$. The Total influential dimensions matrix $T_{D}$ needs to be normalized by dividing it using the following formula:

$$
T_{D}=\left[\begin{array}{ccccc}
t_{D}{ }^{1}=\sum_{j=1}^{m} t_{D}^{i j} & \cdots & t_{D}^{1 j} & \cdots & t_{D}^{1 m} \\
\vdots & & \vdots & & \vdots \\
t_{D}^{i 1} & \cdots & t_{D}^{i j} & \cdots & t_{D}^{i m} \\
\vdots & & \vdots & & \vdots \\
t_{D}{ }^{m 1} & \cdots & t_{D}^{m j} & \cdots & t_{D}^{m m}
\end{array}\right] \rightarrow\left[\begin{array}{c}
\sum_{j=1}^{m} t_{D}^{1 j}=t_{D}{ }^{1} \\
\sum_{j=1}^{m} t_{D}{ }^{i j}=t_{D}{ }^{i} \\
\sum_{j=1}^{m} t_{D}{ }^{m j}=t_{D} m
\end{array}\right]
$$

Thus, the total-influential matrix can be normalized and presented as $T_{D}{ }^{\text {nor }}$. Then, the sum of each row can be defined as $t_{D}{ }^{i}=\sum_{j=1}^{m} t_{D}{ }^{i j}$ where $i=1, \ldots, m$, and $T_{D}$ can be normalized by the rows of sums by dividing the elements in each line to the sum of the line noted in Eq. (7). Therefore, a total influential matrix $T_{D}$ can be normalized and represented as $T_{D}{ }^{n o r} . T_{D}{ }^{n o r}=\left[t^{i j} D / t^{i} D\right]_{m \times m}$, as in Eq. (8). Then, each row of the normalized $T_{D}{ }^{n o r}$ can be summed to equal one, so that $\sum_{j=1}^{m} t_{D}{ }^{n o r i j}=1$.

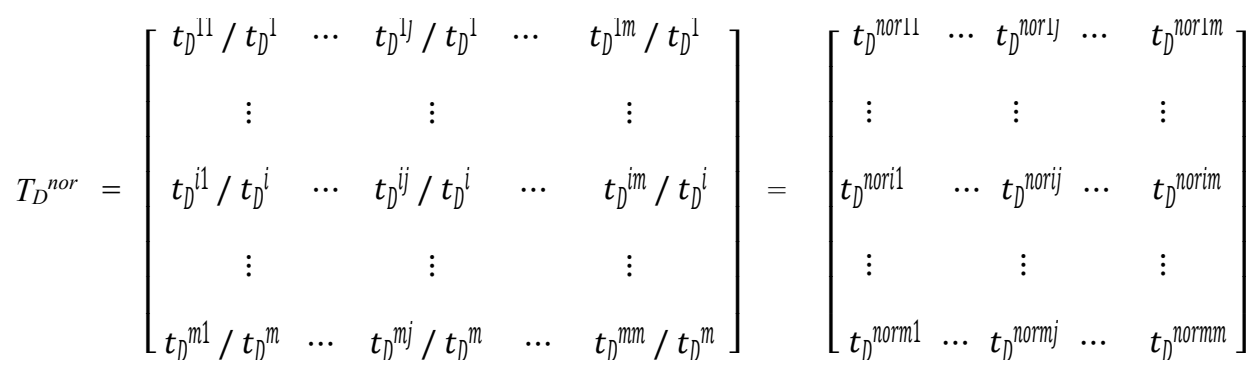

Step 8: Find the normalized Total influential criteria matrix $\boldsymbol{T}_{C}{ }^{\text {nor }}$. The normalized Total-influential criteria matrix $T C^{n o r}$, can be obtained using the Eq. (9).

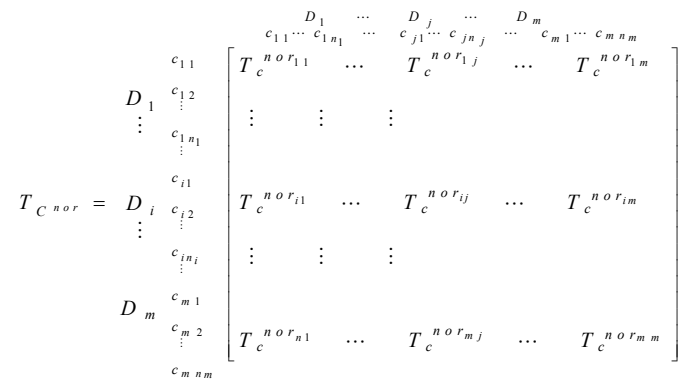

Step 9: Build an un-weighted super-matrix $\boldsymbol{W}_{\boldsymbol{C}}$. Then, the total influential matrix is normalized into a super-matrix according to the interdependence between the relations of the dimensions and related clusters to obtain an un-weighted super-matrix, $W_{C}$, as shown in Eq. (10). Un-weighted super-matrix $W_{C}$ is the matrix transposed from $T_{C}{ }^{n o r}$ (basic concept from the ANP by Saaty, but different from the traditional ANP).

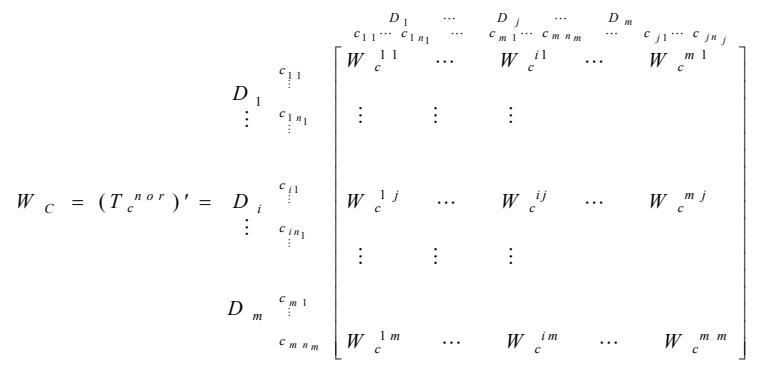


Step 10: Find the influential weights of the DANP. A weighted super-matrix $W_{C}{ }^{*}$ (improving the traditional ANP by using the same weights to make it suitable for the real world) can be obtained by the product of $T_{D}{ }^{\text {nor }}$ and $W_{C}$, i.e., $W_{c}{ }^{*}=T_{D}{ }^{\text {nor }} W_{c}$ by Eq. (11).

$$
W_{c}^{*}=T_{D}{ }^{\text {nor }} \times W_{c}=\left[\begin{array}{ccccc}
t_{D}^{\text {norl }} \times W_{c}^{11} & \cdots & t_{D}^{\text {norl }} \times W_{c}^{11} & \cdots & t_{D}^{\text {norm1 }} \times W_{c}^{m 1} \\
\vdots & & \vdots & & \vdots \\
t_{D}^{\text {norl }} \times W_{c}^{1 j} & \cdots & t_{D}^{\text {norij }} \times W_{c}^{i j} & \cdots & t_{D}^{\text {normj }} \times W_{c}^{m j} \\
\vdots & & \vdots & & \vdots \\
t_{n}^{\text {norlm }} \times W_{c}^{1 m} & \cdots & t_{n}^{\text {norim }} \times W_{c}^{i m} & \cdots & t_{n}^{\text {normm }} \times W_{c}^{m m}
\end{array}\right]
$$

Step 11: Obtain the DANP. Limit the weighted super-matrix by raising it to a sufficiently large power $\varphi$ until it converges and become a long stable super-matrix term to obtain global priority vector, which defines the influential weights $w=\left(w_{1}, \ldots, w_{j}, \ldots, w_{n}\right)$ from $\lim \varphi \rightarrow \infty\left(W_{c}{ }^{*}\right)^{\varphi}$ for the criteria (Chiu et al., 2013).

\section{An empirical case: entrepreneurship policymaking in tourism in Iran}

The aim of this study is introduce and examine a model for national entrepreneurship tourism policy. To this purpose, one of the famous models of entrepreneurship development was selected and criteria's using DANP were weighted and prioritized. For this aim, a new hybrid MCDM model is anticipated which will be assessed by expert groups.

Based on the results, this paper produces an systematic approach for entrepreneurship development in tourism based on hybrid MCDM (multiple criteria decision-making), which shows the network relationships of the policy criteria and proposes the most important dimensions and criteria's for entrepreneurship policymaking in tourism in Iran.

\subsection{Problem descriptions}

Tourism plays a decisive role for country's development and many countries, set development plans based on the tourism and this section become the world's number one industry to 2020. Accordingly, tourism has become one of the main centers of government attention and policies and possible actions for the development of tourism are set. As mentioned at the beginning of the article, statistics shows that tourism section in Iran has been growing in recent years and percentage of tourism in gross domestic product and employment is increasing, but it is ineffectiveness and noncompetitive (Blanke $\&$ Chiesa, 2013). Actually, Iran has high capacity of tourism absorption, but unfortunately the country ignored in her policy statements. Documents for development plan in Iran emphasized on comparative advantage of tourism and its role in economic development. On the other hand, Iran has a lot of capabilities and opportunities in tourism, but there are small share of the revenues allocated to tourism.

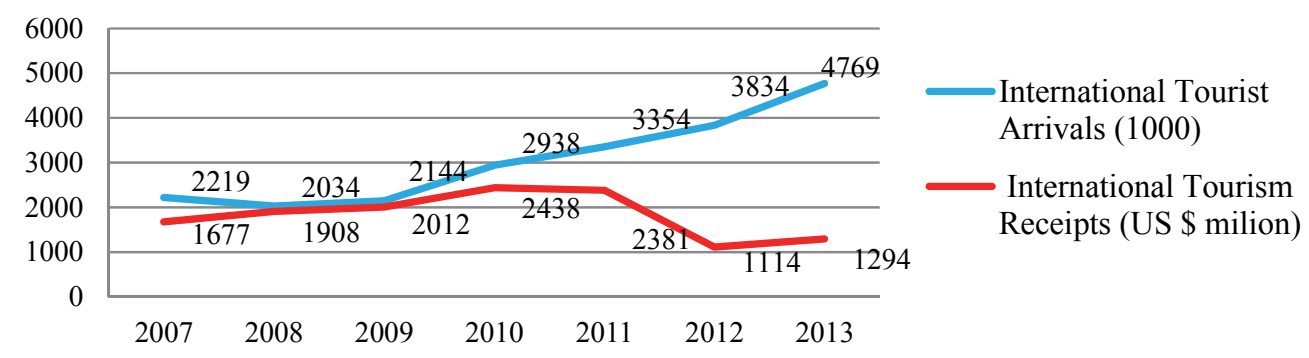

Fig. 4. Iran's International Tourist Arrivals and Receipts 2010 - 2013 (UNWTO, 2013, p. 9) 
Since entrepreneurial businesses are the main actors of tourism, making appropriate policies to promote entrepreneurship in toursim industry is more important than before.

\subsection{Research methodology}

As mentioned in the previous section, in this study we use DANP process for the development of entrepreneurship policy in tourism. The study population consisted of 18 scholars and researchers in the field of tourism, legislators, policy makers and entrepreneurs in tourism. Selected sample based on purposive sampling method and DANP questionnaires were distributed among selected experts. In purposive sampling method, participants who completed the information on this subject are experts in the field (Boswell \& Cannon, 2012; Tashakkori \& Teddlie, 2003).

\subsection{Results and analyses: Illustrate interrelations between policy criteria}

After constructing the measure scales of the direct relation matrix in step 1, a $0-4$ scale measures is used for interrelationships appraise tourism policy criteria by the expert panel. Then, direct-influence matrix is calculated through pair-wise comparison. Then, the direct-influence matrix is obtained in matrix $G$ (Appendix 1). In next step, matrix $G$ is normalized (Appendix 2) and according to step 4, a total-influential matrix $T$ is calculated (Appendix 3 ). In next step, results are analyzed by acquiring $r_{i}+s_{i}$ and $r_{i}-s_{i}$, based on total-influential criteria matrix $T_{C}$, are derived (Appendix 4). After that, in step 6, Sum of influences given and received on dimensions and criteria are presented in Table 2. According to these results, we can map network relations (as shown in Fig. 5).

Based on data from Table 2, Fig. 5 is drawn and network relationship map (NRM) of influential relationships is created. According to these relationships, factor driven economy $\left(\mathrm{D}_{1}\right)$ is located in a higher position and can affect the other dimensions,directly. After that, there is efficiency driven economy $\left(D_{2}\right)$, which influences on innovation driven economy $\left(D_{3}\right)$. In addition, criteria related to any of the dimensions are illustrated in Fig. 5. In addition, the relationships between criteria and their influences on each other are shown in Fig. 5.

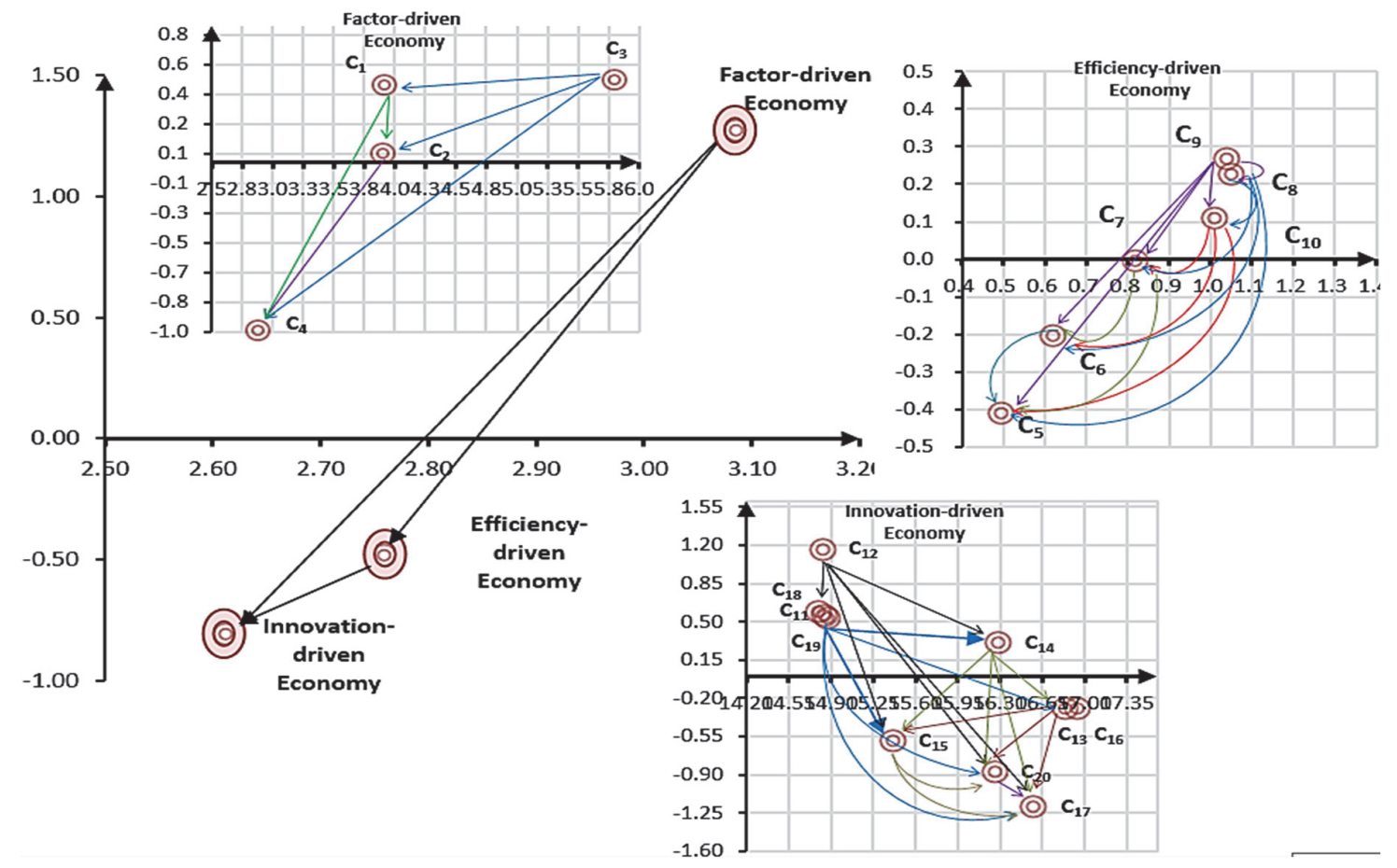

Fig. 5. The NRM of influential relationships within entrepreneurship policy system 
For example, the factor of driven economy $\left(\mathrm{D}_{1}\right)$ and the stability of the business environment $\left(\mathrm{C}_{3}\right)$ influence on other criteria's in category of factor driven economy. Accordingly, Legal and administrative framework $\left(\mathrm{C}_{1}\right)$ influences on Development of infrastructure $\left(\mathrm{C}_{2}\right)$ and Essential health care and basic education $\left(\mathrm{C}_{4}\right)$. Eventually, Development of infrastructure $\left(\mathrm{C}_{2}\right)$ influences on Essential health care and basic education $\left(\mathrm{C}_{4}\right)$.

Based on these findings, not only policymakers can identify the most important factors in tourism entrepreneurship development, but also they make it easy to identify priority through the complex criteria.

Table 2

Sum of influences given and received on dimensions and criteria

\begin{tabular}{|c|c|c|c|c|}
\hline Dimensions / Criteria & $\mathbf{r}_{\mathbf{i}}$ & $\mathbf{S}_{\mathbf{i}}$ & $\mathbf{r}_{\mathbf{i}+\mathbf{S}_{\mathbf{i}}}$ & $\mathbf{r}_{\mathrm{i}-\mathbf{S}_{\mathrm{i}}}$ \\
\hline Basic Requirements $\left(D_{1}\right)$ & 2.182 & 0.903 & 3.086 & 1.279 \\
\hline Legal and administrative framework $\left(\mathrm{C}_{1}\right)$ & 2.187 & 1.730 & 3.917 & 0.457 \\
\hline Development of infrastructure $\left(\mathrm{C}_{2}\right)$ & 1.975 & 1.925 & 3.899 & 0.050 \\
\hline The stability of the business environment $\left(\mathrm{C}_{3}\right)$ & 3.146 & 2.656 & 5.802 & 0.490 \\
\hline Essential health care and basic education $\left(\mathrm{C}_{4}\right)$ & 0.942 & 1.940 & 2.882 & -0.997 \\
\hline Efficiency Enhancers $\left(D_{2}\right)$ & 1.141 & 1.617 & 2.758 & -0.476 \\
\hline Product and service market efficiency $\left(\mathrm{C}_{5}\right)$ & 0.043 & 0.447 & 0.490 & -0.405 \\
\hline Labor market efficiency $\left(\mathrm{C}_{6}\right)$ & 0.209 & 0.409 & 0.617 & -0.200 \\
\hline Sufficient technological readiness $\left(\mathrm{C}_{7}\right)$ & 0.408 & 0.409 & 0.816 & -0.001 \\
\hline Higher education $\left(\mathrm{C}_{8}\right)$ & 0.635 & 0.409 & 1.044 & 0.227 \\
\hline The efficiency of financial markets $\left(\mathrm{C}_{9}\right)$ & 0.652 & 0.383 & 1.034 & 0.269 \\
\hline The effective size of the market $\left(\mathrm{C}_{10}\right)$ & 0.558 & 0.447 & 1.005 & 0.110 \\
\hline Innovation Drivers $\left(\mathrm{D}_{3}\right)$ & 0.903 & 1.706 & 2.610 & -0.803 \\
\hline Entrepreneurial Finance $\left(\mathrm{C}_{11}\right)$ & 7.154 & 7.708 & 14.862 & 0.553 \\
\hline Government Policy $\left(\mathrm{C}_{12}\right)$ & 6.819 & 7.998 & 14.817 & 1.179 \\
\hline Intellectual property rights $\left(\mathrm{C}_{13}\right)$ & 8.559 & 8.269 & 16.828 & -0.290 \\
\hline $\mathrm{R} \& \mathrm{D}$ transfer $\left(\mathrm{C}_{14}\right)$ & 7.980 & 8.297 & 16.277 & 0.318 \\
\hline Physical infrastructure $\left(\mathrm{C}_{15}\right)$ & 7.989 & 7.409 & 15.398 & -0.580 \\
\hline Cultural and social norms $\left(\mathrm{C}_{16}\right)$ & 8.609 & 8.319 & 16.928 & -0.290 \\
\hline Government Entrepreneurship Programs $\left(\mathrm{C}_{17}\right)$ & 8.878 & 7.698 & 16.576 & -1.180 \\
\hline Entrepreneurship education $\left(\mathrm{C}_{18}\right)$ & 7.137 & 7.697 & 14.834 & 0.560 \\
\hline Entry regulation $\left(\mathrm{C}_{19}\right)$ & 7.099 & 7.698 & 14.797 & 0.599 \\
\hline Commercial and Legal infrastructure $\left(\mathrm{C}_{20}\right)$ & 8.558 & 7.688 & 16.246 & -0.870 \\
\hline
\end{tabular}

\subsection{Calculating the weights by DANP model}

In previous steps, we illustrate influential relations between dimensions and criteria by DEMATEL technique. Then we constitute network relations map (NRM) by Sum of influences given and received on dimensions and criteria for entrepreneurship policymaking in tourism. In this step, results of the previous steps must be weighted by ANP technique and interfering relations with the criteria which confirms and we can attain the most accurate weights. For this aims, we must compare the interdependence between criteria's related to each dimensions in the entire systems (see Fig. 3) and then to build an un-weighted super-matrix (Appendix 5) and weighted super-matrix (Appendix 6) through pair-wise comparisons. At the end of this process, we can attain influential weights related to dimensions (Table no. 3). As noted in this table, the most important dimensions by stable matrix of DANP respectively are Basic Requirements, Efficiency Enhancers, and Innovation Drivers.

Table 3

Influential weights related to dimensions by stable matrix of DANP

\begin{tabular}{cccc}
\hline \multirow{2}{*}{$\begin{array}{c}\text { Dimensions } \\
\text { weight }\end{array}$} & Basic Requirements $\left(\mathbf{D}_{\mathbf{1}}\right)$ & Efficiency Enhancers $\left(\mathbf{D}_{\mathbf{2}}\right)$ & Innovation Drivers $\left(\mathbf{D}_{\mathbf{3}}\right)$ \\
\cline { 2 - 4 } & 0.506 & 0.270 & 0.233 \\
\hline
\end{tabular}

Also, influential weights related to different criteria by stable matrix of DANP are shown in Table 4. Moreover, in this table, we calculate the relative weights for all criteria related to dimensions weights. 
Table 4

Influential weights related to criterias by stable matrix of DANP

\begin{tabular}{lcc}
\hline Criteria weight & weight & Relative weight \\
\hline Legal and administrative framework $\left(\mathrm{C}_{1}\right)$ & 0.266 & 0.134 \\
Development of infrastructure $\left(\mathrm{C}_{2}\right)$ & 0.241 & 0.122 \\
The stability of the business environment $\left(\mathrm{C}_{3}\right)$ & 0.381 & 0.193 \\
Essential health care and basic education $\left(\mathrm{C}_{4}\right)$ & 0.113 & 0.057 \\
Product and service market efficiency $\left(\mathrm{C}_{5}\right)$ & 0.017 & 0.005 \\
Labor market efficiency $\left(\mathrm{C}_{6}\right)$ & 0.084 & 0.023 \\
Sufficient technological readiness $\left(\mathrm{C}_{7}\right)$ & 0.163 & 0.044 \\
Higher education $\left(\mathrm{C}_{8}\right)$ & 0.254 & 0.069 \\
The efficiency of financial markets $\left(\mathrm{C}_{9}\right)$ & 0.260 & 0.070 \\
The effective size of the market $\left(\mathrm{C}_{10}\right)$ & 0.222 & 0.060 \\
Entrepreneurial Finance $\left(\mathrm{C}_{11}\right)$ & 0.091 & 0.021 \\
Government Policy $\left(\mathrm{C}_{12}\right)$ & 0.087 & 0.020 \\
Intellectual property rights $\left(\mathrm{C}_{13}\right)$ & 0.109 & 0.025 \\
R\&D transfer $\left(\mathrm{C}_{14}\right)$ & 0.101 & 0.024 \\
Physical infrastructure $\left(\mathrm{C}_{15}\right)$ & 0.101 \\
Cultural and social norms $\left(\mathrm{C}_{16}\right)$ & 0.109 & 0.024 \\
Government Entrepreneurship Programs $\left(\mathrm{C}_{17}\right)$ & 0.113 & 0.025 \\
Entrepreneurship education $\left(\mathrm{C}_{18}\right)$ & 0.091 & 0.026 \\
Entry regulation $\left(\mathrm{C}_{19}\right)$ & 0.090 & 0.021 \\
Commercial and Legal infrastructure $\left(\mathrm{C}_{20}\right)$ & 0.109 & 0.021 \\
\hline
\end{tabular}

\section{Conclusions}

Tourism has several effects on economic growth and become one of the main centers of government attention. Tourism is formed of multiple businesses, which provide a variety of services. Because businesses play an important role in tourism, in this study, we have presented a model for national entrepreneurship tourism policy for policymakers. In this study, we have used Global Entrepreneurship Monitor (GEM) model for entrepreneurship development in tourism. This model contains three steps classified into factor-driven, efficiency-driven and innovation-driven economies. This categorization pursued the 2008 Global Competitiveness Report which was introduced by Porter and related to entrepreneurship interact with economic development (Bosma et al., 2009, p. 4). So, the dimensions of this study are three levels of economic development and related criteria. In this study, we have used a new hybrid MCDM model assessed by a group of experts. A decision-making trial and evaluation laboratory (DEMATEL) has been used to identify complex relations and to form a network relation map (NRM), which includes criteria for tourism policy. Then, the DANP (DEMATEL-based ANP) method has been used to calculate the influential weights of policy criteria to solve problems of dependence and feedback among criteria and alternatives, due to the ANP theory. Results have shown that the most influential dimensions is entrepreneurship policymaking in tourism in factor-driven economy with 0.506 weights followed by Efficiency Enhancers in efficiency-driven economy with the weight of 0.270 and Innovation Drivers in innovation-driven economy with the weight of 0.233 . We also gave weight criteria related to each dimensions. Results have shown the most important criteria for entrepreneurship development in tourism was the stability of the business environment with the relative weight of 0.193 and the lowest criteria was product and service market efficiency with the relative weight of 0.005 . This study can help policymakers set up tourism policy with regards to entrepreneurship for fostering SME's in tourism industry. To improve entrepreneurship situation in factor-driven economy, policymakers need to improve basic requirements. Basic requirements include four criteria including legal and administrative framework, development of infrastructure, the stability of the business environment and essential health care and basic education. Based on the results, policymakers for promoting entrepreneurship in tourism, first should improve the stability of the business environment. Then they must attend to legal and administrative framework. After these criteria, policymakers must develop infrastructure and finally should follow essential health care and basic education. In efficiency-driven economies, policymakers should extents efficiency enhancer criteria respectively: the efficiency of financial markets, higher education, the effective size of the market, sufficient technological readiness, labor market efficiency and product and service market efficiency. Similarly, based on the extracted weights, for entrepreneurship development in tourism in 
innovation-driven economy, policymakers must consider innovation drivers following to government Entrepreneurship Program, intellectual property right, cultural and social norms, commercial and legal infrastructure, R\&D transfer, physical infrastructure, entrepreneurial Finance, entrepreneurship education, entry regulation, and government Policy. The results can provide new insights facing policy makers to provide a basis for developing a comprehensive program of business development and entrepreneurship in tourism at the national level.

\section{References}

Ács, Z., J. Autio, E., \& Szerb, L. (2016). Global Entrepreneurship Index. The Global Entrepreneurship and Development Institute, Washington, D.C., USA.

Ács, Z., J., \& Szerb, 1. (2007). Entrepreneurship , Economic Growth and Public Policy, Small Business Economics, 28, 109-122.

Ács, Z. J., \& Virgill, N. (2010), Entrepreneurship in Developing Countries, in ACS, Z., \& D. B. Audretsch, (Eds). Handbook of Entrepreneurship Research, Chapter 18, Springer, pp.485-514.

Alvarez, C., Urbano, D., Coduras, A., \& Ruiz-Navarro, J. (2011). Environmental conditions and entrepreneurial activity: a regional comparison in Spain. Journal of Small Business and Enterprise Development, 18(1), 120-140.

Audretsch, D. B., Grilo, I., \& Thurik, A. R. (2007). Explaining entrepreneurship and the role of policy: a framework. The handbook of research on entrepreneurship policy, 1-17.

Anderson, J. E. (2004). Public policy making. New York: Houghton Mifflin.

Blanke, J., \& Chiesa, T. (2013, May). The travel \& tourism competitiveness report 2013. In The World Economic Forum.

Bosma, N., Jones, K., Autio, E. \& Levie, J. (2008). Global entrepreneurship monitor. 2007 executive report. Babson College, London Business School, and Global Entrepreneurship Research Consortium (GERA).

Boswell, C., \& Cannon, Sh. (2012). Introduction to Nursing Research. Burlington, MA: Jones \& Bartlett Publishers.

Chen, F. H., Hsu, T. S., \& Tzeng, G. H. (2011). A balanced scorecard approach to establish a performance evaluation and relationship model for hot spring hotels based on a hybrid MCDM model combining DEMATEL and ANP. International Journal of Hospitality Management, 30, 908-932.

Chiu, W. Y., Tzeng, G. H., \& Li, H. L. (2013). A new hybrid MCDM model combining DANP with VIKOR to improve e-store business. Knowledge-Based Systems, 37, 48-61.

Decelle, X. (2004). A conceptual and dynamic approach to innovation in tourism. Maître de Conférences, Institut de Recherches et d'Etudes Supérieures du Tourisme (Irest) Université Paris 1 Panthéon-Sorbonne, France.

Garcia, F. A. (2014). A comparative study of the evolution of tourism policy in Spain and Portugal. Tourism Management Perspectives, 11, 34-50.

Hamzah, A. (2004). Policy and planning of the tourism industry in Malaysia; The 6th. ADRF General Meeting, 2004 Bangkok, Thailand.

Hall, C. M., \& Jenkins, J. (2004). Tourism and public policy. A companion to tourism, 525.

Henrekson, M., \& Stenkula, M., (2010), Entrepreneurship and Public Policy, in ACS, Z., \& D. B. Audretsch, (eds). Handbook of Entrepreneurship Research, Chapter 21, Springer, pp.595-637.

Hu, S. K., Lu, M. T., \& Tzeng, G. H. (2014). Exploring smart phone improvements based on a hybrid MCDM model. Expert Systems with Applications, 41(9), 4401-4413.

Jaafar, M., Abdul-Aziz, A. R., Maideen, S. A., \& Mohd, S. Z. (2011). Entrepreneurship in the tourism industry: Issues in developing countries. International Journal of Hospitality Management, 30(4), 827-835.

Liu, C. H., Tzeng, G. H., \& Lee, M. H. (2012). Improving tourism policy implementation-The use of hybrid MCDM models. Tourism Management, 33(2), 413-426. 
Lundström, A., \& Stevenson, L. (2002). On the Road to Entrepreneurship Policy. Volume 1 of the Entrepreneurship Policy for the Future Series. Örebro: FSF.

Lordkipanidze, M., Brezet, H., \& Backman, M. (2005). The entrepreneurship factor in sustainable tourism development. Journal of Cleaner Production, 13(8), 787-798.

Marzuki, A. (2010). Tourism development in Malaysia. A review on federal government policies. Theoretical and Empirical Researches in Urban Management, (17), 85.

Najda-Janoszka, M., \& Kopera, S. (2014). Exploring barriers to innovation in tourism industry-the case of southern region of Poland. Procedia-Social and Behavioral Sciences, 110, 190-201.

Norbäck, P. J., Persson, L., \& Douhan, R. (2014). Entrepreneurship policy and globalization. Journal of Development Economics, 110, 22-38.

Nybakk, E., \& Hansen, E. (2008). Entrepreneurial attitude, innovation and performance among Norwegian nature-based tourism enterprises. Forest Policy and Economics, 10(7), 473-479.

Ou Yang, Y. P., Shieh, H. M., Leu, J. D., \& Tzeng, G. H. (2008). A novel hybrid MCDM model combined with DEMATEL and ANP with applications. International Journal of Operations Research, 5(3), 160-168.

Redford, T. D. (2012), Entrepreneurship and Public Policy for today and tomorrow's Portuguese Republic, Working paper, Portuguese Studies Program, University of California, Berkeley.

Rigby, J., \& Ramlogan, R., (2013), The Impact and Effectiveness of Entrepreneurship Policy. Nesta Working Paper No. 13/01.

Saufi, A. (2013), Understanding host community's experiences in establishing and developing small tourism enterprises in Lombok, Indonesia, Ph.D. thesis, Griffith University.

Stevenson, L. \& Lundström, A., (2001). Entrepreneurship policy for the future: best practice components, Keynote Presentation at the 46th World Conference of the International, Council for Small Business, June 18.

Stevenson, 1. \& Lundström, A., (2007), Dressing the emperor: the fabric of entrepreneurship policy, in D. B. Audretsch, I. Grilo, \& A. R. Thurik (eds). Handbook of Research on Entrepreneurship Policy. Cheltanham: Edward Elgar, pp. 94 - 130.

Tashakkori, A. Teddlie, C. (2003). Handbook of mixed methods in social \& behavioral research. Thousand Oaks, Calif.; London: SAGE Publications.

Thomas, R., Shaw, G., \& Page, S. J. (2011). Understanding small firms in tourism: A perspective on research trends and challenges. Tourism Management, 32(5), 963-976.

Tourism strategy of turkey (2007-2023). Ministry of Culture \& Tourism.

Tsai, W. H., \& Kuo, H. C. (2011). Entrepreneurship policy evaluation and decision analysis for SMEs. Expert Systems with Applications, 38(7), 8343-8351.

Tzeng, G. H., \& Huang, C. Y. (2012). Combined DEMATEL technique with hybrid MCDM methods for creating the aspired intelligent global manufacturing \& logistics systems. Annals of Operations Research, 197(1), 159-190.

Uriely, N., Yonay, Y., \& Simchai, D. (2002). Backpacking and tourist experience: A type and form analysis. Annals of Tourism Research, 10(1), 87-107.

United Nations World Tourism Organization (UNWTO). (2015). Tourism Highlights. http://www.eunwto.org/doi/book/10.18111/9789284416899.

World Tourism Organization (UNWTO). (2013). Tourism Highlights. www.eunwto.org/doi/pdf/10.18111/9789284415427.

World Tourism Organization (UNWTO). (2011). Tourism Highlights. http://www.eunwto.org/doi/book/10.18111/9789284413935.

Wang, D., \& Ap, J. (2013). Factors affecting tourism policy implementation: A conceptual framework and a case study in China. Tourism Management, 36, 221-233. 

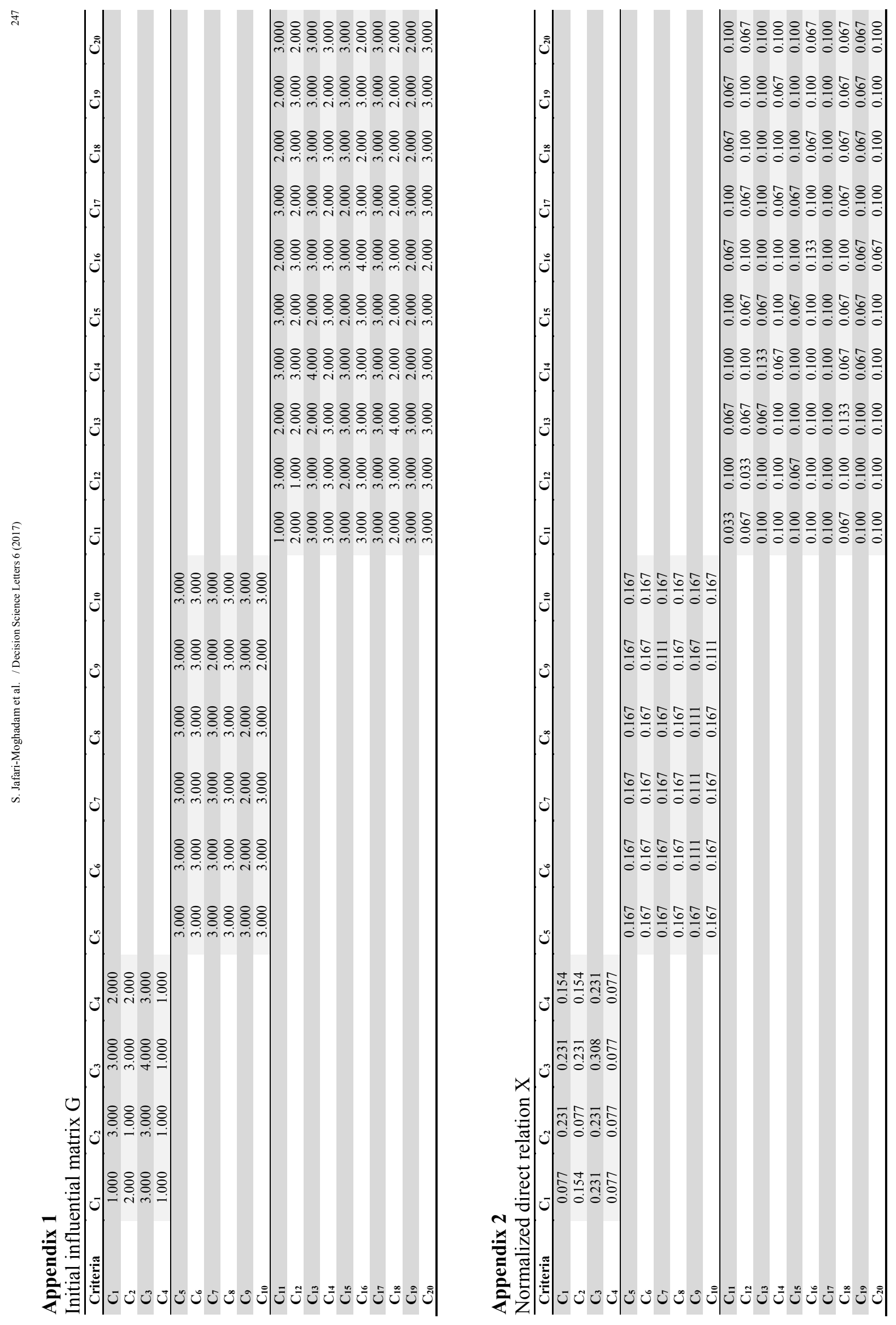


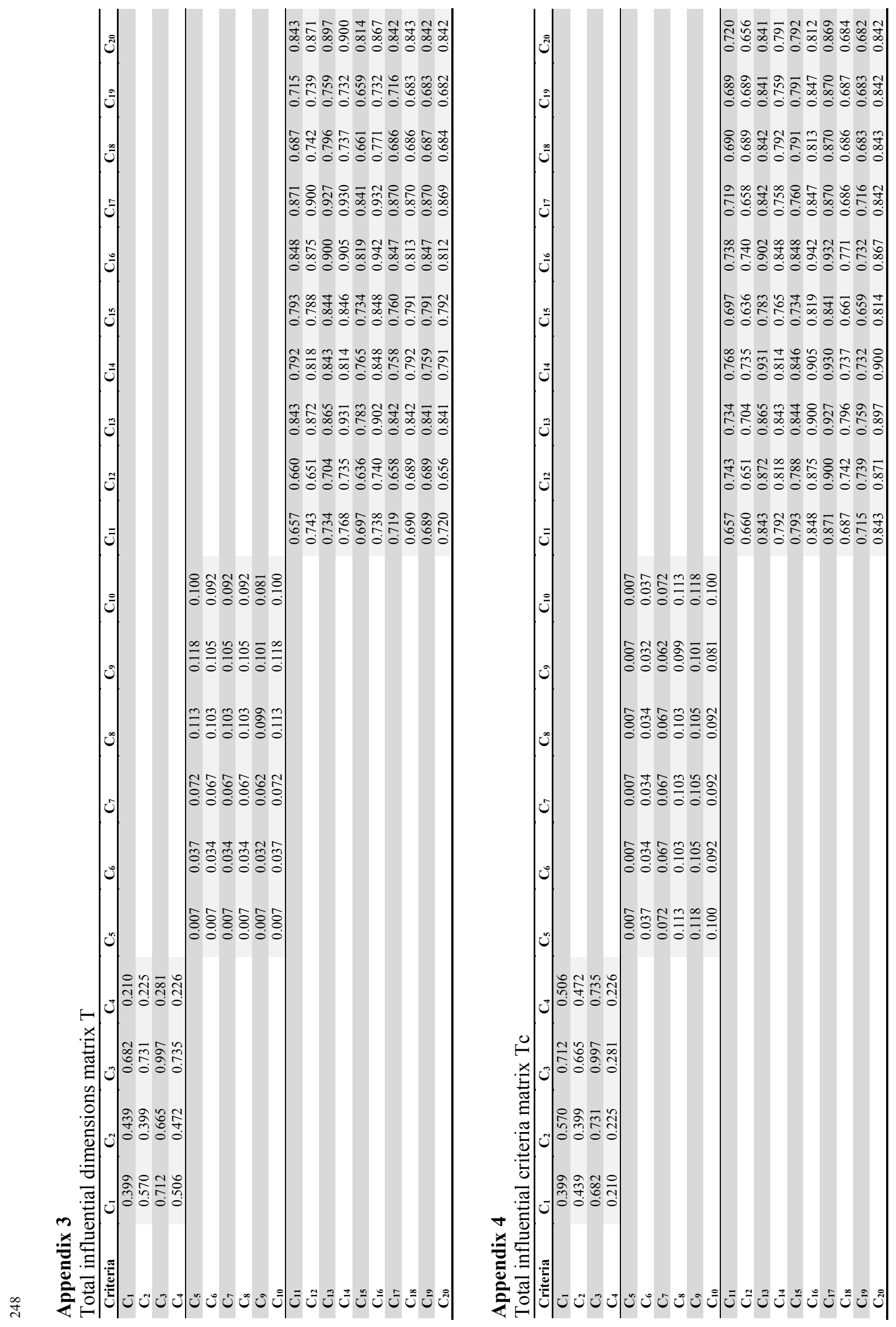



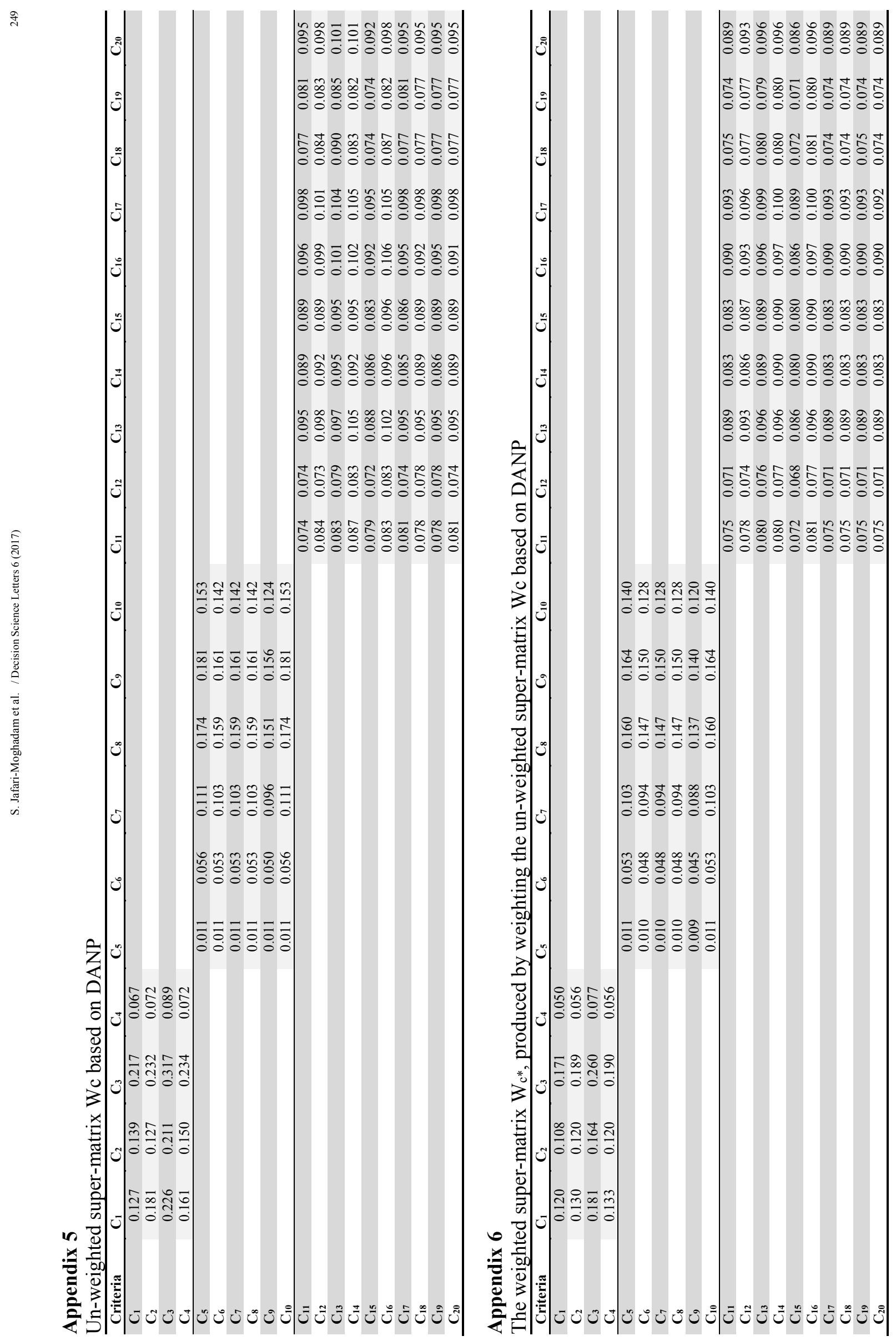
(C) 2017 by the authors; licensee Growing Science, Canada. This is an open access article distributed under the terms and conditions of the Creative Commons Attribution (CC-BY) license (http://creativecommons.org/licenses/by/4.0/). 